\title{
Prevention of ventilator-associated pneumonia by selective decontamination of the digestive tract
}

\section{To the Editors:}

We read with interest the review entitled "Evidence on measures for the prevention of ventilator-associated pneumonia" by LORENTE et al. [1]. We enjoyed the paper as it is comprehensive and based on an appropriate design. In particular, we welcome the authors' acknowledgement of the proven clinical benefits of selective decontamination of the digestive tract (SDD). The authors give four explanations why SDD is not yet widely used, but are unable to make a definitive recommendation regarding its use due to the perceived "lack of consistent benefit and unclear cost-effectiveness".
Overall, 20 yrs of clinical research have yielded 56 randomised controlled trials (RCTs) of SDD and 12 meta-analyses [2]. SDD significantly reduced the odds ratio ( $95 \%$ confidence interval) for pneumonia [3], bloodstream infection [4] and mortality [3] to $0.35(0.29-0.41), 0.63(0.46-0.87)$ and $0.78 \quad(0.68-0.89)$, respectively.

Concerns expressed by the experts about resistance are based on low-level evidence but have hindered the implementation of SDD. Resistance was practically absent in 56 RCTs of SDD [5]. In particular, a large Dutch RCT including the end-point of resistance demonstrated that carriage of multiresistant, aerobic,

TABLE 1 Summary of randomised controlled trials of selective decontamination of the digestive tract, including data on costs

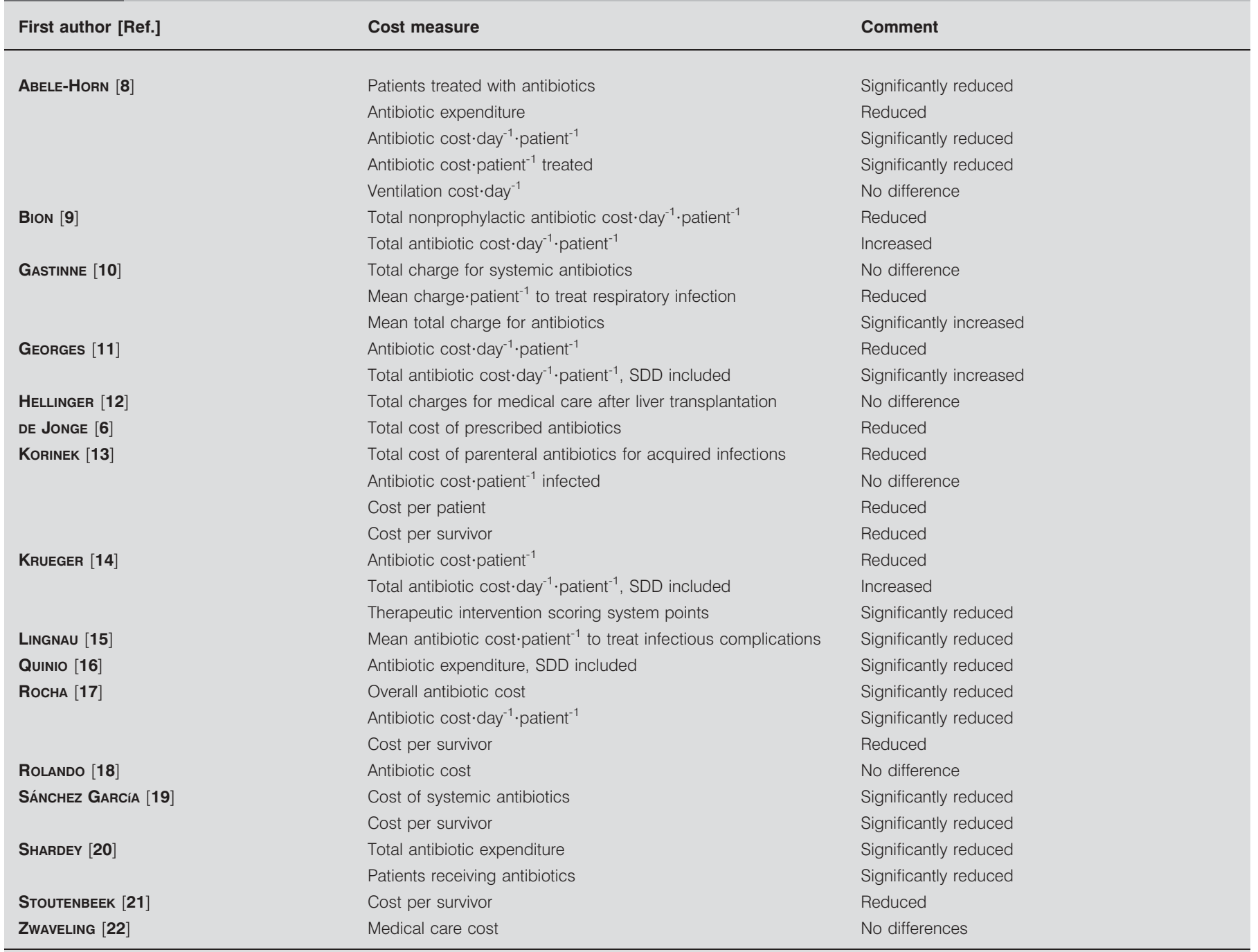

Data were retrieved after reviewing 56 randomised controlled trials of selective decontamination of the digestive tract (SDD) $[4,5]$. 
Gram-negative bacilli was significantly reduced by SDD [6], and a French RCT showed that SDD controlled an outbreak caused by extended-spectrum $\beta$-lactamase-producing Klebsiella pneumoniae [7]. Additionally, resistance was not a clinical problem in 10 studies that monitored resistance over a period of 2-9 yrs [2].

Costs were evaluated in 16 RCTs of SDD (table 1). Costs were reduced in the majority of studies; only three trials showed an increase in total costs. Interestingly, four studies showed that cost per survivor was lower in patients receiving SDD compared with controls. In addition, VAN NIEUWENHOVEN et al. [23], using a combination of crude cost analysis, decision model analysis and bootstrap analysis, provided strong evidence that preventing ventilator-associated pneumonia by means of oropharyngeal decontamination was cost-effective and was the dominant strategy, i.e. had lower costs and beneficial effects.

We believe that an additional cost of selective decontamination of the digestive tract of $\sim € 6$ per day can hardly be an issue for an intervention that significantly reduces lower airway and bloodstream infections, and mortality, without antimicrobial resistance emerging in unselected critically ill patients [24].

\section{Silvestri*, H.K.F. van Saene", M.A. de la Cal ${ }^{\natural}$, R.E. Sarginson ${ }^{+}$and C. Thomann*}

*Emergency Dept, Unit of Anaesthesia and Intensive Care, Presidio Ospedaliero, Gorizia, Italy, "Dept of Medical Microbiology, University of Liverpool, 'Paediatric Intensive Care Unit, Alder Hey Children's Hospital, Liverpool, UK, and 'Intensive Care Unit, University Hospital, Getafe, Madrid, Spain.

\section{STATEMENT OF INTEREST}

None declared.

\section{REFERENCES}

1 Lorente L, Blot S, Rello J. Evidence on measures for the prevention of ventilator-associated pneumonia. Eur Respir J 2007; 30: 1193-1207.

2 Silvestri L, van Saene HK, Thomann C, Perić M. Selective decontamination of the digestive tract reduces pneumonia and mortality without resistance emerging. Am J Infect Control 2007; 35: 354-357.

3 Liberati A, D'Amico R, Pifferi S, Torri V, Brazzi L. Antibiotic prophylaxis to reduce respiratory tract infections and mortality in adults receiving intensive care. Cochrane Database Syst Rev 2004; 1: CD000022.

4 Silvestri L, van Saene HK, Milanese M, Gregori D, Gullo A. Selective decontamination of the digestive tract reduces bacterial bloodstream infection and mortality in critically ill patients. Systematic review of randomized, controlled trials. J Hosp Infect 2007; 65: 187-203.

5 Silvestri L, van Saene HK. Selective decontamination of the digestive tract does not increase resistance in critically ill patients: evidence from randomized controlled trials. Crit Care Med 2006; 34: 2027-2029.

6 de Jonge E, Schultz MJ, Spanjaard L, et al. Effects of selective decontamination of digestive tract on mortality and acquisition of resistant bacteria in intensive care: a randomised controlled trial. Lancet 2003; 362: 1011-1016.
7 Brun-Buisson C, Legrand P, Rauss A, et al. Intestinal decontamination for control of nosocomial multiresistant gram-negative bacilli. Study of an outbreak in an intensive care unit. Ann Intern Med 1989; 110: 873-881.

8 Abele-Horn M, Dauber A, Bauernfeind A, et al. Decrease in nosocomial pneumonia in ventilated patients by selective oropharyngeal decontamination (SOD). Intensive Care Med 1997; 23: 187-195.

9 Bion JF, Badger I, Crosby HA, et al. Selective decontamination of the digestive tract reduces gram-negative pulmonary colonization but not systemic endotoxemia in patients undergoing elective liver transplantation. Crit Care Med 1994; 22: 40-49.

10 Gastinne H, Wolff M, Delatour F, Faurisson F, Chevret S. A controlled trial in intensive care units of selective decontamination of the digestive tract with nonabsorbable antibiotics. The French Study Group on Selective Decontamination of the Digestive Tract. N Engl J Med 1992; 326: 594-599.

11 Georges B, Mazerolles M, Decun JF, et al. Décontamination digestive sélective: résultats d'une étude chez le polytraumatisé [Selective decontamination of the digestive tract: results of a study in polytrauma]. Réanimation Urgences 1994; 3: 621-627.

12 Hellinger WC, Yao JD, Alvarez S, et al. A randomized, prospective, double-blinded evaluation of selective bowel decontamination in liver transplantation. Transplantation 2002; 73: 1904-1909.

13 Korinek AM, Laisne MJ, Nicolas MH, Raskine L, Deroin V, Sanson-Lepors MJ. Selective decontamination of the digestive tract in neurosurgical intensive care unit patients: a double-blind, randomized, placebo-controlled study. Crit Care Med 1993; 21: 1466-1473.

14 Krueger WA, Lenhart FP, Neeser G, et al. Influence of combined intravenous and topical antibiotic prophylaxis on the incidence of infections, organ dysfunctions, and mortality in critically ill surgical patients: a prospective, stratified, randomized, double-blind, placebo-controlled clinical trial. Am J Respir Crit Care Med 2002; 166: 1029-1037.

15 Lingnau W, Berger J, Javorsky F, Lejeune P, Mutz N, Benzer H. Selective intestinal decontamination in multiple trauma patients: prospective, controlled trial. J Trauma 1997; 42: 687-694.

16 Quinio B, Albanèse J, Bues-Charbit M, Viviand X, Martin C. Selective decontamination of the digestive tract in multiple trauma patients. A prospective double-blind, randomized, placebo-controlled study. Chest 1996; 109: 765-772.

17 Rocha LA, Martín MJ, Pita S, et al. Prevention of nosocomial infection in critically ill patients by selective decontamination of the digestive tract. A randomized, double blind, placebo-controlled study. Intensive Care Med 1992; 18: 398-404.

18 Rolando N, Gimson A, Wade J, Philpott-Howard J, Casewell M, Williams R. Prospective controlled trial of selective parenteral and enteral antimicrobial regimen in fulminant liver failure. Hepatology 1993; 17: 196-201.

19 Sánchez García M, Cambronero Galache JA, López Diaz J, et al. Effectiveness and cost of selective decontamination of the digestive tract in critically ill intubated patients. A randomized, double-blind, placebo-controlled, multicenter trial. Am J Respir Crit Care Med 1998; 158: 908-916. 
20 Schardey HM, Joosten U, Finke U, et al. The prevention of anastomotic leakage after total gastrectomy with local decontamination. A prospective, randomized, doubleblind, placebo-controlled multicenter trial. Ann Surg 1997; 225: $172-180$.

21 Stoutenbeek CP, van Saene HK, Zandstra DF. Prevention of multiple organ failure by selective decontamination of the digestive tract in multiple trauma patients. In: Faist E, Baue AE, Schildberg FW, eds. The Immune Consequences of Trauma, Shock and Sepsis - Mechanisms and Therapeutic Approaches. Lengerich, Pabst Science Publishers, 1996; pp. 1055-1066.

22 Zwaveling JH, Maring JK, Klompmaker IJ, et al. Selective decontamination of the digestive tract to prevent postoperative infection: a randomized placebo-controlled trial in liver transplant patients. Crit Care Med 2002; 30: 1204-1209.

23 van Nieuwenhoven CA, Buskens E, Bergmans DC, van Tiel FH, Ramsay G, Bonten MJ. Oral decontamination is cost-saving in the prevention of ventilator-associated pneumonia in intensive care units. Crit Care Med 2004; 32: 126-130.

24 van Saene HK, Silvestri L, de la Cal MA, Sarginson RE. Selective decontamination of the digestive tract reduces lower airway and bloodstream infection and mortality and prevents emergence of antimicrobial resistance. Microbes Infect 2006; 8: 953-954.

\section{Comparisons between portable and chemoluminescence exhaled nitric oxide measurements}

\section{To the Editors:}

Exhaled nitric oxide fraction ( $F$ eNO), a well-established marker of eosinophilic airway inflammation is elevated in asthma [1, 2]. A recent study showed that changes in FeNO are correlated with changes in asthma control over time in unselected patients [3]. It was also shown that monitoring FeNO enables anti-inflammatory treatment to be tailored more efficiently, thereby resulting in the reduction of inhaled corticosteroid doses without compromising asthma control [4]. Although a more recent study may slightly temper this enthusiasm [5], all these data suggest that FeNO measurement may be helpful in day-to-day asthma management and should, therefore, be integrated into routine testing procedures. So far, however, FeNO has been measured mostly with chemoluminescence equipment that is expensive and bulky, thereby restricting its use in specialised centres. Cheaper handheld devices (NIOX MINO; Aerocrine AB, Solna, Sweden) using an electrochemical sensor to measure FeNO are now available [6] and should allow widespread use of FeNO evaluation in asthma management. The few existing studies that have investigated FeNO measurements achieved with NIOX MINO suggest that FeNO is well correlated (albeit slightly higher) with FeNO measured using the larger chemoluminescence analyser provided by the same manufacturer (Aerocrine AB) [7-9].

In a comparative study, we used both NIOX MINO and a daily calibrated LR-2000 chemoluminescence analyser (Logan Research Ltd, Rochester, UK) to measure FeNO in 102 subjects, including 58 asthma patients (43 patients were treated with inhaled steroids) and 44 nonasthmatic control subjects. Our results confirm that FeNO measured by using NIOX MINO in accordance with manufacturer's instructions is highly correlated $(r=0.957, p<0.001)$ but consistently higher $(p<0.001$ by paired t-test on log-transformed FeNO) than FeNO measured by using our chemoluminescence analyser in accordance with the American Thoracic Society/European Respiratory Society guidelines. A Bland-Altman plot of log transformed FeNO (fig. 1) shows a mean difference equal to 0.144 corresponding to a mean ratio of 1.39 between NIOX MINO and our chemoluminescence analyser (39\% difference). This did not prevent FeNO measurements, obtained with the two devices, to be similarly reliable in discriminating asthma patients from nonasthma subjects (i.e. similar area under the curve on the receiver operating characteristic curve analysis; data not shown). However the optimal FeNO cut-off points that

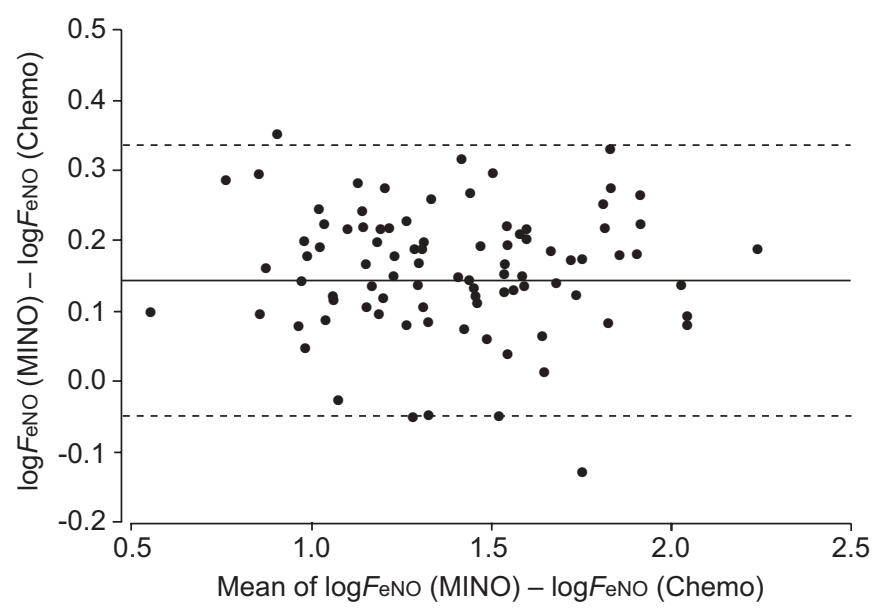

FIGURE 1. Bland--Altman plot comparing log transformed exhaled nitric oxide fraction ( $F$ eNO) from NIOX MINO (MINO; Aerocrine $A B$ ) and chemoluminescence (Chemo) devices. —: mean difference; ----: $\pm 2 \times \mathrm{SD}$. 